\title{
ANALISIS PENGARUH TOTAL ASET TERHADAP PROPORSI PENDAPATAN OPERASIONAL SELAIN BUNGA DENGAN LDR (LOAN TO DEPOSIT RATIO) SEBAGAI VARIABEL MODERATING PADA INDUSTRI PERBANKAN DI INDONESIA
}

\author{
Mega Sukmawati dan Muchlis \\ Prodi Akuntansi STIE Dr KHEZ Muttaqien \\ mega.sukmawati88@gmail.com dan muchlis_seakmbm@yahoo.com
}

\begin{abstract}
This study aims to determine the effect of Total Assets of the proportion of Non-Interest Operating Income with the Loan to Deposit Ratio (LDR) as a moderating variable in the banking industry in Indonesia which is expected to be useful for the banking sector in Indonesia as inputs in order to increase the income of banks in Indonesia and is expected to create new policies in the banking world in its operations so as to increase the income of banks in Indonesia. This research is a causal research that aims to test hypotheses about the influence of independent variables on the dependent variable with quantitative descriptive approach. After going through the screening of the outlier sample in this study was a conventional bank whose financial statements published by Bank Indonesia in the years 2009-2013 as many as 106 banks. The test equipment used is the analysis of multiple regression analysis. The results showed that in testing hypotheses about the effect of total assets to the proportion of non-interest operating income obtained $t_{\text {count }}>t_{\text {table }}$ is 4,844 >1,983 so the variable total assets significantly influence the proportion of non-interest operating income in the banking industry in Indonesia amounted to $18.4 \%$. Simultaneously there is significant influence between the total assets, the Loan to Deposit Ratio (LDR) and the interaction between total assets and LDR to the proportion of noninterest operating income amounted to $27.5 \%$. and Loan to Deposit Ratio (LDR) affect the size of the effect of total assets to the proportion of non-interest operating income in the banking industry in Indonesia with large influence is $57.68 \%$.
\end{abstract}

Keywords : Total Assets, Proportion of Non-Interest Operating Income, Loan to Deposit Ratio (LDR).

\section{PENDAHULUAN}

Peranan perbankan sangat mempengaruhi kegiatan ekonomi suatu negara. Perbankan memiliki kedudukan yang strategis, yakni sebagai penunjang kelancaran sistem pembayaran, pelaksanaan kebijakan moneter dan pencapaian stabilitas sistem keuangan, sehingga diperlukan perbankan yang sehat, transparan dan dapat dipertanggungjawabkan (OJK 2014: 9). Oleh karena itu, kemajuan suatu bank di suatu negara dapat pula dijadikan ukuran kemajuan negara yang bersangkutan. Semakin maju suatu negara, maka semakin besar peranan perbankan dalam mengendalikan negara tersebut.

Usaha-usaha pokok perbankan diupayakan agar tetap berjalan dengan baik dan lancar serta didasarkan pada prinsip saling percaya antara bank dengan masyarakat selaku pihak ketiga yang menyerahkan dananya untuk selanjutnya dikelola lebih produktif. Berdasarkan hal tersebut maka masalah yang dihadapi oleh setiap bank adalah bagaimana cara pengumpulan dana dari masyarakat, kemudian mengelolanya dana tersebut secara tepat agar dapat memberikan keuntungan bagi kedua belah pihak. Sehingga tingkat kepercayaan masyarakat akan sangat tergantung pada baik 
buruknya kondisi perusahaan tersebut, hal ini dapat dilihat dari salah satu kinerja perusahaan tersebut dalam aspek keuangan perusahaan yang bersangkutan.

Dari aktivitas bank menyalurkan dana masyarakat kepada pihak yang membutuhkan melalui penyaluran kredit, bank mendapatkan bunga kredit. Pendapatan ini merupakan pendapatan utama bagi bank, terutama bankbank konvensional. Keadaan ini menjadikan bank-bank berupaya untuk meningkatkan penyaluran kredit kepada debitur, untuk meningkatkan pendapatannya. Namun permasalahan lain yang dihadapi oleh manajemen Bank, ketika keadaan perekonomian Indonesia memburuk, setelah terjadinya krisis ekonomi yang berkepanjangan, yang mana banyak permasalahan kredit macet, karena banyaknya perusahaan yang tidak mampu melanjutkan usahanya, sementara itu tingkat suku bunga kredit mengalami kenaikan yang tinggi. Kondisi ini menjadikan banyak bank yang mengalami permasalahan finansial, sehingga dilikuidasi karena tidak mampu memenuhi persyaratan yang ditetapkan oleh Bank Indonesia sebagai bank yang sehat.

Walaupun pada saat ini kondisi perekonomian Indonesia berangsur membaik, namun manajemen bank sangat berhati-hati dalam menyalurkan kredit, karena menghindari risiko kredit macet yang

\section{KAJIAN TEORI}

Pengertian bank menurut Kasmir (2013: 3) adalah lembaga keuangan yang kegiatan usahanya adalah menghimpun dana dari masyarakat dan menyalurkan kembali dana tersebut ke masyarakat serta memberikan jasa-jasa bank lainnya.

Aktiva adalah manfaat ekonomi yang dinyatakan untuk sumber-sumber ekonomi yang dimiliki perusahaan, yang meliputi barang dan hak-hak yang memberikan manfaat di masa yang akan datang dan didapat dari transaksi-transaksi atau peristiwa yang terjadi di masa lalu (Taswan 2013: 11). Penggunaan dana bank tercantum pada sisi aktiva, yang terdiri dari aktiva yang tidak menghasilkan dan aktiva yang menghasilkan. Aktiva yang tidak menghasilkan terdiri dari primary reserve mungkin terjadi. Pengalaman tersebut menjadikan bank berupaya mencari solusi untuk menghasilkan pendapatan lain selain dari bunga kredit. Salah satu strategi yang banyak dipilih oleh manajemen bank dalam meningkatkan pendapatannya adalah dengan menggali dan meningkatkan pendapatannya dari pendapatan operasional selain bunga.

Penggalian pendapatan lain selain bunga kredit merupakan salah satu upaya manajemen bank dalam meningkatkan pendapatan, menjaga stabilitas pendapatan finansial, mengingat pendapatan dari bunga kredit sering berubah karena besarnya ketetapan suku bunga kredit dari Bank Indonesia, maupun kemampuan bank dalam menyalurkan kredit kepada masyrakat. Saat ini bank-bank sudah mulai mengembangkan jasa-jasa melalui teknologi dan sumber daya yang ada untuk meraih keuntungan di luar pendapatan bunga kredit. Tujuan penelitian ini adalah sebagai berikut :

1) Untuk menganalisis besarnya pengaruh total aset terhadap proporsi pendapatan operasional selain bunga industri perbankan di Indonesia.

2) Untuk menganalisis LDR (Loan to Deposit Ratio) mempengaruhi besar kecilnya pengaruh total aset terhadap proporsi pendapatan operasional selain bunga pada industri perbankan di Indonesia.

dan penanaman dalam aktiva tetap. Sedangkan aktiva yang menghasilkan terdiri dari secondary reserve, kredit yang diberikan dan investasi dana jangka panjang (penyertaan).

Pendapatan non-operasional terdiri dari keuntungan penjualan aktiva tetap, pendapatan sewa, bunga antar kantor, dan pendapatan non-operasional lainnya baik dalam bentuk rupiah maupun valas.

LDR (Loan to Deposit Ratio) adalah rasio perhitungan jumlah kredit yang diberikan terhadap dana pihak ketiga. Kredit yang diberikan merupakan kredit yang diberikan kepada pihak ketiga (tidak termasuk kredit yang diberikan pada bank lain). Yang termasuk dana pihak ketiga dalam rasio ini mencakup giro, tabungan, 
deposito (tidak termasuk giro dan deposito antar bank).

Penelitian sebelumnya telah dilakukan oleh beberapa peneliti untuk mengetahui bahwa Loan to Deposit Ratio (LDR) mempengaruhi besar kecilnya pengaruh Total Aset terhadap Pendapatan Operasional Selain Bunga. Penelitian tersebut diantaranya sebagai berikut :

1) Berdasarkan penelitian Young dan Rice (2013) yang bertujuan untuk mengetahui pengaruh Pendapatan Selain Bunga dan Kinerja Keuangan pada Bank Komersial di USA. Pendapatan selain bunga menyumbang lebih dari $40 \%$ dari pendapatan operasional industri perbankan komersial di USA. Tulisan ini menunjukkan sejumlah link empiris antara pendapatan selain bunga bank, strategi bisnis, kondisi pasar, perubahan teknologi, dan kinerja keuangan antara tahun 1989 dan 2001. Hasil penelitian menunjukkan bahwa bank yang dikelola dengan baik secara bertahap mengalami peningkatan pendapatan selain bunga. Temuan ini menunjukkan bahwa pendapatan selain bunga bekerja sama dan bukan menggantikan pendapatan bunga dari kegiatan intermediasi yang merupakan fungsi inti bank. Di antara tahun 1980 dan 2001 pendapatan selain bunga bank komersial di USA meningkat dari 0,77\% menjadi 2,39\% dari aset industri perbankan agregat, dan meningkat dari 20,31\% menjadi $42,20 \%$ dari agregat pendapatan operasional industri perbankan. Meningkatnya pendapatan selain bunga di bank-bank komersial telah banyak didokumentasikan dan dibahas dalam pers industri dan peraturan publikasi (misalnya: Feldman dan Schmidt 1999), namun hanya beberapa studi akademis telah menyelidiki dampak peningkatan pendapatan selain bunga pada kinerja keuangan bank komersial. Sementara itu bank-bank besar dan bank dengan strategi khusus (misalnya: bank kartu kredit, KPR bank) lebih mengandalkan pendapatan selain bunga dibandingkan bank-bank kecil dengan strategi bisnis tradisional, ada pemahaman yang sistematis kecil mengapa penghasilan selain bunga bervariasi di bank dan bagaimana pendapatan selain bunga dikaitkan dengan kinerja keuangan perbankan. Menurut teori ini, bank mendapatkan keuntungan dari dana simpanan dengan tingkat bunga rendah, kemudian menjual dana tersebut dengan tingkat bunga yang lebih tinggi. Sampai saat ini, bank komersial berhubungan erat dengan bank di model-model teoritis ini. Tapi selama dua dekade terakhir bank komersial AS telah mengandalkan pendapatan selain bunga, banyak yang tidak mengandalkan dana simpanan dan dana pinjaman lagi. Aktivitas intermediasi menjadi kurang efektif untuk kesehatan keuangan dan strategi bisnis bank komersial sedangkan pendapatan selain bunga dan selain intermediasi menjadi lebih penting. Hasil penelitian ini menemukan bahwa bank yang besar dapat menumbuhkan pendapatan selain bunga seiring dengan perkembangan teknologi, bank dengan teknologi tinggi berpengaruh pada pendapatan selain bunga. Bank yang dikelola dengan baik ternyata tidak terlalu mengandalkan pendapatan selain bunga, makin besar bank maka makin besar pendapatan selain bunganya. Hasil penelitian ini membentuk hipotesis yaitu Aset mempunyai pengaruh positif terhadap Pendapatan Selain Bunga.

2) Berdasarkan penelitian Priyatmoko (2014) yang bertujuan untuk mengetahui Pengaruh Pendapatan Bunga Kredit dan Pendapatan Selain Bunga (Fee Based Income) terhadap Kinerja Keuangan Bank (Return On Asset) (Studi Kasus pada Bank Umum Milik Negara Periode 2007 - 2011). Pertumbuhan kredit bank umum pada periode 2007 2008 terus mengalami penurunan, namun pada periode 2008 - 2009 ada peningkatan sebesar $0,53 \%$, sementara pada periode 2009 - 2011 mengalami penurunan yang tajam dari tahun 2009 sebesar 88,49\% menjadi 79,86\% pada tahun 2011. Peningkatan pendapatan bunga yang terjadi pada periode 2008 - 2009 dikarenakan pada tahun tersebut suku bunga kredit mengalami penurunan. Hal ini sesuai dengan data yang dirilis Bank Indonesia yaitu rata-rata suku bunga kredit telah membaik pada tahun 2008 - 2011, dimana suku bunga pada 2008 mencapai 15,39\%, kemudian turun menjadi $14,37 \%$ pada 
2009. Suku bunga pada 2010 menjadi $13,24 \%$, pada 2011 menjadi $12,74 \%$. Meskipun suku bunga kredit mengalami penurunan, namun minat para nasabah untuk meminjam dana tidak begitu antusias dalam meminjam dana. Rata-rata ROA tahun 2006 - 2010 telah mencapai standar ukuran Bank di Indonesia yaitu di atas $1,5 \%$, pada tahun 2007 ROA mengalami penurunan walaupun masih berada di atas standar ukuran bank di Indonesia yaitu $1,5 \%$. Dalam perkembangannya ROA selama 2006 - 2007 mengalami penurunan yaitu $2,65 \%$ pada tahun 2006 , kemudian turun menjadi $2,33 \%$ pada tahun 2007, kemudian ROA turun lagi menjadi 2,10\% pada tahun 2008. Kemudian mengalami penurunan pada tahun 2009 menjadi 2,03\% dan menurun lagi pada 2010 menjadi $2,01 \%$. ROA bank mengalami penurunan dari tahun 2006 - 2010 walaupun presentasenya kecil. Pada saat ini perbankan tidak hanya mengandalkan pendapatan yang dihasilkan dari bunga kredit atau dikenal dengan pendapatan bunga kredit, akan tetapi juga untuk meningkatkan profitabilitas, maka perbankan harus pintar atau jeli dengan berupaya mencari sumber-sumber atau produk-produk diluar dari kegiatan perkreditan, seperti dari jasa-jasa perbankan yang diberikan atau yang lebih dikenal dengan fee based income, hal ini menjadi pilar pembentuk profit bagi perbankan. Dengan adanya fee based income, maka pendapatan menjadi naik dan kinerja keuangan menjadi semakin baik, hal ini dapat dilihat dengan adanya perubahan pada Return On Assets yang semakin meningkat. Penelitian ini bertujuan untuk mengetahui pengaruh simultan pendapatan bunga kredit dan pendapatan selain bunga terhadap kinerja keuangan bank dan mengetahui pengaruh parsial pendapatan bunga kredit dan pendapatan selain bunga terhadap kinerja keuangan bank. Penelitian ini menggunakan metode regresi linier panel dengan tujuan untuk mengetahui adanya pengaruh antara lebih dari satu peubah bebas terhadap satu peubah terikat pada data yang merupakan kombinasi dari data time series dan data cross section. Hasil pengolah data menggunakan metode regresi berganda panel menunjukkan persamaan model regresi berganda yang dapat menggambarkan model dari pengaruh yang berbeda dari tiap-tiap variabel independen (pendapatan bunga kredit dan pendapatan selain bunga) terhadap variabel dependent (Return On Asset). Untuk pemilihan model digunakan metode Redundant Fixed Effect Test dan Correlated Random Effects - Hausman Test. Kedua pengujian tersebut digunakan untuk membandingkan antara Fixed Effect Model (FEM) dan Random Effect Model (REM). Hipotesis yang digunakan pada kedua pengujian tersebut adalah:

$\mathrm{H}_{0}$ : Model yang digunakan adalah Random Effect Model (REM) .

$\mathrm{H}_{1}$ : Model yang digunakan adalah Fixed Effect Model (FEM).

Kaidah pengambilan keputusan dalam kedua pengujian tersebut adalah dengan menggunakan nilai signifikansi, di mana jika nilai signifikansi lebih besar dari alpha $5 \%$ maka hipotesis $\mathrm{H}_{0}$ yang diterima, dan jika nilai signifikansi lebih kecil dari alpha $5 \%$, maka hipotesis $\mathrm{H}_{1}$ yang diterima. Hal tersebut dapat diperhatikan bahwa nilai signifikansi pada kedua pengujian adalah 0,000 dan lebih kecil dari alpha 5\%, sehingga hipotesis $\mathrm{H}_{1}$ diterima dan digunakan Fixed Effects Model (FEM) untuk mengestimasi data panel dengan menambahkan variabel dummy. Dalam Fixed Effects Model (FEM) digunakan konstanta dari masing-masing bank untuk menggambarkan karakter dari masingmasing bank yang diamati. Fixed Effect Model (FEM) untuk mengetahui apakah variabel dependen mempunyai pengaruh terhadap variabel independen. Penelitian Priyatmoko (2014) yang menghasilkan kesimpulan bahwa Variabel Pendapatan Bunga maupun variabel Pendapatan Selain Bunga memiliki pengaruh yang signifikan terhadap variabel Return On Asset.

3) Penelitian yang dilakukan Sahpony, dkk (2009) Studi Kasus PT. Bank Bengkulu bertujuan untuk mengetahui pengaruh variabel Aset Total (AT), Dana Pihak Ketiga (DPK), Pendapatan Non Bunga (PNB), dan Ekuitas (EK) terhadap Laba Bersih (LB) yang telah berhasil diraih oleh PT Bank Bengkulu selama kurun waktu 
dari tahun 1999 sampai dengan tahun 2008. Tujuan tersebut sangat penting berdasarkan pertimbangan adanya kepentingan para pemegang saham PT Bank Bengkulu yang terdiri dari: para Bupati/Wali Kota seluruh Provinsi Bengkulu. Para pemegang saham tersebut ingin memaksimalkan pembagian dividen dari investasi dana yang mereka setorkan sebagai modal penyertaan kepada PT Bank Bengkulu. Objek penelitian ini adalah Laporan Keuangan PT Bank Bengkulu yang terdiri dari Neraca dan Laporan Rugi/Laba dari Kwartal I Tahun 1999 sampai dengan Kwartal IV Tahun 2008. Data sekunder tentang Neraca dan Laporan Rugi/Laba dikumpulkan dari dokumen yang tersedia pada bagian arsip atas persetujuan Direksi PT Bank Bengkulu. Metode analisis yang digunakan adalah statistik regresi berganda, dalam penelitian ini Laba Bersih merupakan variabel dependen (terpengaruh), sedangkan Aset Total, Pendapatan Non Bunga, Dana Pihak Ketiga, dan Ekuitas merupakan variabel-variabel

(berpengaruh). Hasil regresi dengan menggunakan berbagai metode membuktikan bahwa hanya Pendapatan Non Bunga (PNB) dan Ekuitas (EK) yang secara signifikan berpengaruh terhadap Laba Bersih (LB) PT Bank Bengkulu. Meskipun hasil regresi tidak bisa membuktikan pengaruh secara keseluruhan variabel-variabel Aset Total, Pendapatan Non Bunga, Dana Pihak Ketiga, dan Ekuitas terhadap Laba Bersih. Direksi PT Bank Bengkulu sebaiknya tetap harus mempertimbangkan adanya pengaruh Aset Total (AT) dan Dana Pihak Ketiga (DPK)

\section{METODE PENELITIAN}

Jenis penelitian yang digunakan dalam penelitian ini adalah penelitian kausal yang bertujuan untuk menguji hipotesis tentang pengaruh satu (variabel independen) terhadap variabel lainnya (variabel dependen). Dengan menggunakan pendekatan penelitian deskriptif kuantitatif akan memberikan pemahaman yang lebih mudah dalam melihat fenomena yang terjadi pada hubungan antara total aset yang mempengaruhi pendapatan operasional terhadap Laba Bersih (LB). Bagaimanapun Aset Total dan Dana Pihak Ketiga merupakan faktor-faktor penting yang harus mendapatkan perhatian manajemen perbankan.

4) Berdasarkan penelitian Rastito (2008) bertujuan untuk mengetahui besarnya pengaruh dari faktor aset total yang dimiliki bank, kredit yang diberikan bank dan pendapatan bunga bank secara bersamasama terhadap laba yang diperoleh bank pada industri perbankan di Indonesia serta mengetahui faktor apa yang paling berpengaruh terhadap laba bank pada kelompok bank (BUMN, BUSN Devisa, BUSN Non Devisa, BPD, Bank Campuran dan Bank Asing). Penelitian dilakukan dengan mengambil sampel dari industri perbankan di Indonesia dari tahun 2002 2006 yang laporan keuangannya tersedia secara lengkap dan dipublikasikan oleh situs resmi Bank Indonesia. Sampel yang diambil sebanyak 99 bank. Faktor-faktor yang diteliti adalah aset total yang dimiliki bank, kredit yang diberikan bank dan pendapatan bunga bank, kemudian ketiga variabel tersebut kemudian diregresi terhadap faktor laba yang diperoleh masingmasing bank pada tahun berjalan. Hasil regresi tersebut selanjutnya diuji untuk melihat apakah hipotesis yang ada sesuai dengan hasil regresi tersebut. Hasil penelitian yang dilakukan Rastito (2008) adalah Variabel Aset Total yang dimiliki bank, Kredit yang diberikan bank dan Pendapatan bunga bank berpengaruh signifikan terhadap Laba yang diperoleh industri perbankan.

selain bunga dengan LDR (Loan to Deposit Ratio) sebagai variabel moderating.

Variabel penelitian yang digunakan dalam penelitian ini adalah Variabel Total Aset $\left(\mathrm{X}_{1}\right)$ menggunakan data yang diperoleh dari laporan keuangan seluruh bank konvensional di Indonesia yang berjumlah 108 bank selama lima tahun dari tahun 2009 - 2013. Variabel Pendapatan Operasional Selain Bunga $\left(\mathrm{Y}_{1}\right)$ menggunakan data yang diperoleh dari 
laporan keuangan seluruh bank konvensional di Indonesia yang berjumlah 108 bank selama lima tahun dari tahun 2009 - 2013. Dan LDR (Loan to Deposit Ratio) $\left(\mathrm{X}_{2}\right)$ sebagai variabel moderator yang juga merupakan variabel independen kedua menggunakan data yang diperoleh dari laporan keuangan seluruh bank konvensional di Indonesia yang berjumlah 108 bank selama lima tahun dari tahun 2009 - 2013

Data yang digunakan dalam penelitian ini adalah data sekunder berupa laporan keuangan dan rasio perbankan, maka populasi penelitian ini terdiri dari seluruh Bank Konvensional yang laporan keuangannya dipublikasikan oleh Bank Indonesia pada tahun 2009 - 2013. Pengambilan sampel dalam penelitian ini menggunakan metode purposive sampling yaitu pemilihan sampel berdasarkan kriteria dengan tujuan untuk mendapatkan sampel yang representatif dan benar-benar dapat mewakili populasinya.

Teknik pengumpulan data dalam penelitian ini adalah dengan penggunaan metode dokumentasi, yaitu mencari data mengenai hal-hal atau variabel berupa catatan, buku, dan sebagainya. Sedangkan sumber data yang digunakan adalah data sekunder, yaitu teknik pengumpulan data dengan cara memanfaatkan laporan keuangan perbankan di Indonesia yang dipublikasikan oleh Bank Indonesia pada tahun 2009-2013.

Peneliti menggunakan alat uji analisis regresi linier berganda dengan rumus yang dipakai adalah sebagai berikut:

$$
\mathrm{Y}^{*}=a+b X_{1}{ }^{*}+c X_{2}+d X_{1} X_{2}+\mathrm{e}
$$

Keterangan:

$\mathrm{Y}^{*}=$ Pendapatan Operasional

Selain Bunga (Ln)

$\mathrm{a}=$ Koefisien konstanta

$\mathrm{X}_{1}{ }^{*}=$ Total Aset (Ln)

$\mathrm{X}_{2}=$ LDR (Loan to Deposit Ratio)

$\mathrm{b}, \mathrm{c}, \mathrm{d}=$ Koefisien regresi dari masing-masing variabel independen

$\mathrm{e}=$ Error

Menurut Sunyoto (2011:131) mengungkapkan bahwa model regresi linier berganda dapat disebut baik jika terbebas dari asumsi-asumsi klasik statistik, yaitu multikolinieritas, heteroskedastisitas, autokorelasi, dan normalitas data.

1) Uji Normalitas

Uji normalitas data untuk menguji data variabel bebas dan data variabel terikat pada persamaan regresi yang dihasilkan. Persamaan regresi dikatakan baik jika mempunyai data variabel bebas dan data variabel terikat berdistribusi normal.

Uji asumsi klasik dengan cara statistik dalam menguji data variabel bebas dan data variabel terikat berdistribusi normal atau tidak pada cara statistik ini melalui nilai kemiringan kurva (skew-ness $=\alpha 3$ ) atau nilai keruncingan kurva (kurtosis $=\alpha 4$ ) diperbandingkan dengan nilai $\mathrm{Z}$ tabel.

2) Uji Multikolinieritas

Uji asumsi ini diterapkan untuk analisis regresi berganda yang terdiri atas dua atau lebih variabel bebas, dimana akan diukur tingkat asosiasi (keeratan) hubungan/pengaruh antar variabel bebas tersebut melalui besaran koefisien regresi (r). Dikatakan terjadi multikolinieritas, jika koefisien regresi antar variabel bebas lebih besar dari 0,90. Dikatakan tidak terjadi multikolinieritas jika koefisien regresi antar variabel bebas lebih kecil atau sama dengan 0,90. Variabel bebas mengalami multikolinieritas jika: $\alpha$ hitung $<\alpha$ dan VIF hitung > VIF. Variabel bebas tidak mengalami multikolinieritas jika: $\alpha$ hitung $>\alpha$ dan VIF hitung $<$ VIF.

3) Uji Heteroskedastisitas

Analisis uji asumsi heteroskedastisitas hasil output SPSS melalui grafik scatterplot antara $\mathrm{Z}$ prediction (ZPRED) yang merupakan variabel bebas (sumbu $\mathrm{X}=\mathrm{Y}$ hasil prediksi) dan nilai residualnya (SRESID) merupakan variabel terikat (sumbu $\mathrm{Y}=\mathrm{Y}$ prediksi $-\mathrm{Y}$ riil).

\section{4) Uji Autokorelasi}

Persamaan regresi yang baik adalah yang tidak memiliki masalah autokorelasi, jika terjadi autokorelasi maka persamaan tersebut menjadi tidak baik/ tidak layak dipakai prediksi. Masalah autokorelasi baru timbul jika ada korelasi secara linier antara kesalahan pengganggu periode $\mathrm{t}$ (berada) dengan kesalahan pengganggu periode $\mathrm{t}-1$ 
(sebelumnya). Salah satu ukuran ada tidaknya masalah autokorelasi dengan uji Durbin-Watson (DW) dengan ketentuan sebagai berikut: (1) Terjadi autokorelasi positif, jika nilai DW di bawah -2 (DW < 2); (2) Terjadi autokorelasi positif, jika nilai DW di antara -2 dan +2 ; dan (3) Terjadi autokorelasi negative, jika nilai DW di atas +2 atau $\mathrm{DW}>+2$.

Pengujian hipotesis dalam penelitian ini adalah sebagai berikut :

a) Analisis Koefisien Regresi

Regresi ini digunakan untuk mengukur derajat hubungan serta arah hubungan antara variabel independen yaitu variabel independen Total Aset $\left(\mathrm{X}_{1}\right)$ dengan variabel dependennya yaitu Proporsi pendapatan operasional selain bunga pada industri perbankan di Indonesia.

b) Analisis Koefisien Determinasi $\left(\mathrm{R}^{2}\right)$

Koefisien determinasi $\left(\mathrm{R}^{2}\right)$ pada intinya mengukur seberapa jauh kemampuan model dalam menerangkan variasi variabel dependen. Nilai koefisien determinasi adalah antara nol dan satu (Ghozali, 2011:97). Interpretasi: Jika $\mathrm{R}^{2}$ mendekati 1 (semakin besar nilai $\mathrm{R}^{2}$ ), menunjukkan bahwa kontribusi variabel bebas terhadap variabel terikat secara simultan semakin kuat; dan Jika $\mathrm{R}^{2}$ mendekati 0 (semakin kecil nilai $\mathrm{R}^{2}$ ), menunjukkan bahwa kontribusi variabel

\section{HASIL DAN PEMBAHASAN}

\section{Model Regresi Berganda}

Model regresi berganda yang akan dibentuk adalah sebagai berikut:

$$
\mathrm{Y}^{*}=a+b X_{1}{ }^{*}+c X_{2}+d X_{1} X_{2}+\mathrm{e}
$$

Keterangan:

$$
\mathrm{Y}^{*} \quad=\text { Pendapatan Operasional }
$$

Selain Bunga ( $(\mathrm{Ln})$

$$
\begin{array}{ll}
\mathrm{a} & =\text { Koefisien konstanta } \\
\mathrm{X}_{1}{ }^{*} & =\text { Total Aset }(\mathrm{Ln})
\end{array}
$$

bebas terhadap variabel terikat secara simultan semakin lemah.

c) Uji t (Pengujian secara parsial)

Uji t digunakan untuk mengetahui ada tidaknya hubungan atau pengaruh yang berarti (signifikan) antara variabel independen secara parsial terhadap variabel dependen (Sunyoto, 2011:146). Adapun kriteria pengujian uji t adalah:

$\mathrm{H}_{0}$ diterima apabila $-t(\alpha / 2 ; d k) \leq t h \leq$ $+t(\alpha / 2 ; d k)$, berarti secara individual tidak ada pengaruh yang sangat kuat signifikan antara variabel independen terhadap variabel dependen.

$\mathrm{H}_{0}$ ditolak apabila th $>$ $+t(\alpha / 2 ; d k)$ atau - th $\leq$ $-t(\alpha / 2 ; d k)$, berarti secara individual ada pengaruh yang sangat kuat signifikan antara variabel independen terhadap variabel dependen.

d) Uji F (Pengujian secara serentak)

Uji F dilakukan untuk mengetahui pengaruh antara variabel independen terhadap variabel dependen secara bersamasama yaitu menggunakan $F$ hitung (Sunyoto, 2011:147). Adapun kriteria pengujian uji $F$ sebagai berikut:

$\mathrm{H}_{0}$ diterima jika : $\mathrm{F}_{\text {hitung }} \leq \mathrm{F}_{\text {Tabel }}$

$\mathrm{H}_{0}$ ditolak jika : $\mathrm{F}_{\text {hitung }} \geq \mathrm{F}_{\text {Tabel }}$

$$
\begin{aligned}
& \mathrm{X}_{2} \quad=\text { LDR (Loan to Deposit } \\
& \text { Ratio) } \quad=\text { Koefisien regresi dari } \\
& \mathrm{b}, \mathrm{c}, \mathrm{d}=\text { variabel independen } \\
& \text { masing-masing variar } \\
& \mathrm{e} \quad=\text { Error }
\end{aligned}
$$

Dengan menggunakan bantuan aplikasi program SPSS, didapat output hasil perhitungan regresi linier berganda sebagai berikut: 
Tabel 4 Hasil Pengujian Analisis Regresi

Coefficients $^{\mathrm{a}}$

\begin{tabular}{|c|c|c|c|c|c|}
\hline \multirow{2}{*}{\multicolumn{2}{|c|}{ Model }} & \multicolumn{2}{|c|}{ Unstandardized Coefficients } & \multirow[b]{2}{*}{$\mathrm{t}$} & \multirow[b]{2}{*}{ Sig. } \\
\hline & & B & Std. Error & & \\
\hline \multirow[t]{4}{*}{1} & $\begin{array}{l}\text { (Consta } \\
\text { nt) }\end{array}$ & 2.983 & 1.485 & 2.009 & .047 \\
\hline & $\begin{array}{l}\text { Total } \\
\text { Aset }\end{array}$ & -.067 & .098 & -.678 & .499 \\
\hline & LDR & -.041 & .015 & -2.745 & .007 \\
\hline & Interaksi & .302 & 101 & 2.992 & .003 \\
\hline
\end{tabular}

a. Dependent Variable: LnPNB

Berdasarkan output di atas didapat nilai kontstanta dan koefisien regresi sehingga dapat dibentuk persamaan regresi linier berganda sebagai berikut: $\mathrm{Y}^{*}=2.983-0.067 \mathrm{X}_{1}{ }^{*}-0.041 \mathrm{X}_{2}+$

$$
0.302 \mathrm{X}_{1} \mathrm{X}_{2}
$$

Persamaan di atas dapat diartikan sebagai berikut :

$\mathrm{b}_{0}=2.983$ artinya jika Total aset, LDR dan Interaksi bernilai nol maka Proporsi pendapatan operasional selain bunga pada industri perbankan di Indonesia bernilai 2.983 .

$\mathrm{b}_{1}=-0.067$ artinya jika Total aset $\left(\mathrm{X}_{1}\right)$ meningkat sebesar satu satuan dan variabel lainnya konstan, maka Proporsi pendapatan operasional selain bunga

1. Analisis Koefisien Regresi Berganda

Untuk mengetahui koefisien regresi berganda SPSS didapat output hasil pada industri perbankan di Indonesia (Y) akan menurun sebesar 0.067 .

$\mathrm{b}_{2}=-0.041$ artinya jika LDR $\left(\mathrm{X}_{2}\right)$ meningkat sebesar satu satuan dan variabel lainnya konstan, maka variabel Proporsi pendapatan operasional selain bunga pada industri perbankan di Indonesia (Y) akan menurun sebesar 0.041 .

$\mathrm{b}_{3}=0.302$ artinya jika Interaksi Total asset dan LDR (Loan to Deposit Ratio) meningkat sebesar satu satuan maka variabel Proporsi pendapatan operasional selain bunga pada industri perbankan di Indonesia (Y) akan meningkat sebesar 0.302 .

estimasi koefisien regresi sebagai berikut

Tabel 5.9 Regresi Berganda dan Koefisien Determinasi Model Summary ${ }^{b}$

\begin{tabular}{|l|l|l|l|l|l|}
\hline $\begin{array}{l}\text { Mo } \\
\text { del }\end{array}$ & $\mathrm{R}$ & $\begin{array}{l}\mathrm{R} \\
\text { Square }\end{array}$ & Adjusted R Square & $\begin{array}{l}\text { Std. Error } \\
\text { of } \\
\text { Estimate }\end{array}$ & $\begin{array}{l}\text { Durbin- } \\
\text { Watson }\end{array}$ \\
\hline 1 & $.524^{\mathrm{a}}$ & .275 & .254 & .67819 & 1.334 \\
\hline
\end{tabular}

a. Predictors: (Constant), Interaksi, Total Aset, LDR

b. Dependent Variable: LnPNB

Berdasarkan hasil perhitungan diatas diperoleh nilai $\mathrm{R}=0.524$, nilai ini menunjukkan adanya hubungan yang sedang antara variabel bebas secara simultan dengan variabel terikat, dimana koefisien regresi tersebut berada pada rentang $0,40-0.60$. Setelah diketahui nilai $\mathrm{R}$ sebesar 0.524 , selanjutnya koefisien determinasi dapat 
dihitung menggunakan rumus sebagai berikut:

$$
\begin{aligned}
\mathrm{KD} & =\mathrm{R}^{2} \text { X } 100 \% \\
& =(0.524)^{2} \times 100 \% \\
& =27.5 \% .
\end{aligned}
$$

Nilai koefisien determinasi sebesar 27.5\% menunjukan bahwa Total aset, LDR dan Interaksi memberikan

\section{PEMBAHASAN}

Berdasarkan hasil perhitungan dengan menggunakan program SPSS dapat disimpulkan bahwa koefisien regresi untuk variabel Total Aset dengan Proporsi pendapatan operasional selain bunga pada industri perbankan di Indonesia diperoleh nilai sebesar 0.429 menunjukkan adanya hubungan positif yang sedang antara Total Aset $\left(\mathrm{X}_{1}\right)$ dengan Proporsi pendapatan operasional selain bunga (Y) pada industri perbankan di Indonesia yang artinya semakin tinggi Total Aset maka semakin tinggi nilai Proporsi pendapatan operasional selain bunga pada industri perbankan di Indonesia sebaliknya jika Total Aset semakin rendah maka nilai Proporsi pendapatan operasional selain bunga pada industri perbankan di Indonesia juga semakin rendah. Hal ini sejalan dengan penelitian Young \& Rice (2003) bahwa aset mempunyai pengaruh positif pada pendapatan operasional selain bunga, juga sejalan dengan penelitian Priyatmoko (2014) yang berlaku kebalikannya bahwa pendapatan operasional selain bunga berpengaruh pada Return On Asset (ROA), secara tidak langsung penelitian ini sejalan dengan penelitian Sahpony, dkk (2009) dan Rastito (2008) yang meneliti adanya pengaruh antara total aset terhadap pendapatan operasional selain bunga yang akan meningkatkan laba bersih perbankan.

Untuk hasil perhitungan koefisien regresi variabel Loan to Deposit Ratio $\left(\mathrm{X}_{2}\right)$ dengan Proporsi Pendapatan Operasional Selain Bunga pada industri perbankan di Indonesia (Y) diperoleh nilai sebesar 0.119 menunjukkan adanya hubungan positif yang sangat rendah antara Loan to Deposit Ratio $\left(\mathrm{X}_{2}\right)$ dengan Proporsi pendapatan pengaruh simultan sebesar $27.5 \%$ terhadap Proporsi pendapatan operasional selain bunga pada industri perbankan di Indonesia (Y) Sedangkan sisanya sebesar $72.5 \%$ dipengaruhi oleh faktor lain yang tidak diamati di dalam penelitian ini. operasional selain bunga pada industri perbankan di Indonesia (Y) dan untuk interaksi antara Total Aset $\left(\mathrm{X}_{1}\right)$ dan Loan to Deposit Ratio $\left(\mathrm{X}_{2}\right)$ dengan Proporsi Pendapatan Operasional Selain Bunga (Y) pada industri perbankan di Indonesia diperoleh nilai sebesar 0.261 menunjukkan adanya hubungan positif yang rendah antara interaksi Total Aset $\left(\mathrm{X}_{1}\right)$ dan Loan to Deposit Ratio $\left(\mathrm{X}_{2}\right)$ dengan Proporsi Pendapatan Operasional Selain Bunga (Y) pada industri perbankan di Indonesia.

Berdasarkan hasil pengujian analisis regresi, variabel Total Aset berpengaruh negatif terhadap Proporsi Pendapatan Operasional Selain Bunga yang artinya semakin tinggi total aset maka semakin rendah proporsi pendapatan operasional selain bunga, hal ini bersamaan dengan variabel LDR yang juga berpengaruh negatif terhadap Proporsi Pendapatan Operasional Selain Bunga yang artinya semakin tinggi LDR, dan variabel lainnya konstan maka semakin rendah variabel Proporsi Pendapatan Operasional Selain Bunga. Sedangkan untuk Interaksi Total Aset dan LDR berpengaruh positif terhadap Proporsi Pendapatan Operasional Selain Bunga yang artinya semakin tinggi Interaksi Total Aset dan LDR maka semakin tinggi juga Proporsi Pendapatan Operasional Selain Bunga.

Berdasarkan Analisis Koefisien Regresi Berganda diperoleh nilai $\mathrm{R}=0,524$ yang menunjukkan adanya hubungan yang sedang antara variabel Total Aset dan LDR secara simultan dengan variabel Proporsi Pendapatan Operasional Selain Bunga, sehingga membentuk nilai koefisien determinasi sebesar $27,5 \%$ yang 
menunjukkan besarnya pengaruh Total Aset, LDR dan Interaksi secara simultan terhadap Proporsi Pendapatan Operasional Selain Bunga.

Berdasarkan uji $\mathrm{t}$ penelitian ini menghasilkan nilai $t_{\text {hitung }}>t_{\text {tabel }}$ yaitu $2.992>$ 1.9835 sehingga $\mathrm{H}_{\mathrm{o}}$ ditolak, yang artinya secara parsial interaksi total aset dan LDR berpengaruh signifikan terhadap proporsi pendapatan operasional selain bunga.

Berdasarkan uji $\mathrm{F}$ penelitian ini menghasilkan nilai $F_{\text {Hitung }}$ lebih besar dari $\mathrm{F}_{\text {tabel }}(12.892>2.6937)$, maka $\mathrm{H}_{0}$ ditolak dan $\mathrm{H}_{1}$ diterima, artinya terdapat pengaruh signifikan secara simultan antara variabel Total aset, Loan to Deposit Ratio (LDR) dan interaksi antara total aset dan LDR terhadap Proporsi pendapatan operasional selain bunga pada industri perbankan di Indonesia.

Penelitian ini menjelaskan bahwa besar kecilnya bank yang diukur melalui total aset tidak dapat mengganti pendapatan bunga dengan pendapatan operasional selain bunga karena menurut penelitian ini total aset berpengaruh positif tingkat sedang

\section{KESIMPULAN DAN SARAN}

Berdasarkan hasil penelitian dan pembahasan mengenai "Analisis Pengaruh Total Aset terhadap Proporsi Pendapatan Operasional Selain Bunga dengan Loan to Deposit Ratio (LDR) sebagai Variabel Moderating pada Industri Perbankan di Indonesia", maka penulis dapat menarik kesimpulan sebagai berikut:

1. Berdasarkan hasil perhitungan koefisien regresi, Total Aset dengan Proporsi Pendapatan Operasional Selain Bunga Pada Industri Perbankan di Indonesia menunjukkan adanya hubungan positif yang sedang artinya semakin tinggi Total Aset maka semakin tinggi nilai Proporsi Pendapatan Operasional Selain Bunga pada Industri Perbankan di Indonesia, sedangkan untuk Loan to Deposit Ratio (LDR) dengan Proporsi Pendapatan Operasional Selain Bunga menunjukkan adanya hubungan positif yang sangat rendah dan untuk Interaksi Total Aset dan Loan to Deposit Ratio (LDR) dengan Proporsi Pendapatan terhadap pendapatan operasional selain bunga. Pendapatan operasional selain bunga dapat dijadikan sebagai pelengkap pendapatan bunga yang merupakan pendapatan utama perbankan. Semakin besar ukuran bank yang diukur dari total aset maka semakin besar pula pendapatan bunga dan pendapatan operasional selain bunga. Hal ini membuktikan bahwa bankbank dengan total aset yang besar tidak bisa hanya mengganti pendapatan bunga dengan pendapatan operasional selain bunga untuk kegiatan operasionalnya. Bank besar juga masih memerlukan pendapatan bunga dari kredit yang diberikan untuk terus meningkatkan total asetnya. Begitu juga dengan bank kecil yang hampir seluruh pendapatannya dari pendapatan bunga. Hal ini sejalan dengan penelitian Young \& Rice (2013) pada bank komersial di USA yang menunjukkan bahwa pendapatan operasional selain bunga bekerja sama dan bukan menggantikan pendapatan bunga yang diperoleh dari kegiatan operasional bank

Operasional Selain Bunga menunjukkan adanya hubungan positif yang rendah.

2. Hasil pengujian analisis regresi, Total Aset dan Loan to Deposit Ratio (LDR) berpengaruh negatif terhadap Proporsi Pendapatan Operasional Selain Bunga yang artinya semakin tinggi Total Aset maka semakin rendah Pendapatan Operasional Selain Bunga dan semakin tinggi Loan to Deposit Ratio (LDR) maka semakin rendah Proporsi Pendapatan Operasional Selain Bunga. Secara simultan terdapat pengaruh signifikan antara variabel Total Aset, Loan to Deposit Ratio (LDR) dan interaksi antara Total Aset dan LDR terhadap Proporsi Pendapatan Operasional Selain Bunga pada Industri Perbankan di Indonesia.

3. Interaksi antara Total Aset dengan Loan to Deposit Ratio (LDR) menunjukkan bahwa $\mathrm{H}_{\mathrm{o}}$ ditolak dan dapat disimpulkan bahwa secara parsial dan 
secara simultan interaksi Total Aset dengan Loan to Deposit Ratio (LDR) berpengaruh signifikan terhadap Proporsi Pendapatan Operasional Selain Bunga pada Industri Perbankan di Indonesia yang artinya bahwa Loan to Deposit Ratio (LDR) mempengaruhi besar kecilnya pengaruh Total Aset terhadap Proporsi Pendapatan Operasional Selain Bunga pada Industri Perbankan di Indonesia.

Berdasarkan hasil penelitian pada bab sebelumnya, maka implikasi pada penelitian ini adalah setiap perbankan yang diikutsertakan dalam penelitian ini harus menjaga nilai total aset dan LDR pada posisi yang seideal mungkin. Hal ini dikarenakan berdasarkan kajian empiris di lapangan diketahui bahwa total aset dan LDR mempunyai pengaruh yang signifikan terhadap proporsi pendapatan operasional selain bunga.

Berdasarkan hasil penelitian yang telah dibahas pada bab sebelumnya maka

\section{DAFTAR PUSTAKA}

DeYoung, Robert and Rice, Tata. (2003). Non Interest Income and Financial Performance at U.S Commercial Banks. Journal of Emerging Issues Series Supervision and Regulation Department Federal Reserve Bank of Chicago : (S\&R-2003-2).

DeYoung, Robert, William C. Hunter, and Gregory F. Udell. (2004). Whither the Community Bank? What We Know and What We Suspect. Journal of Financial Services Research, forthcoming.

Ghozali, Imam. (2011). Aplikasi Analisis Multivariate Dengan Program IBM SPSS 19. Semarang : BP Universitas Diponegoro.

Kasmir. (2013). Dasar - Dasar Perbankan, Edisi Revisi 2012 (cetakan sebelas). Jakarta : PT Raja Grafindo Persada.

Otoritas Jasa Keuangan (OJK). (2014). Booklet Perbankan Indonesia Edisi 1. Jakarta : Departemen Informasi dan Publikasi Perbankan.

Priyatmoko, Wahyu Dwi. (2014). Pengaruh Pendapatan Bunga Kredit dan Pendapatan Selain Bunga (Fee Based Income) terhadap Kinerja Keuangan saran yang bisa diajukan oleh penulis kepada pihak perusahaan dalam hal ini adalah industri perbankan di Indonesia harus memperhatikan nilai Total Aset dan Loan to Deposit Ratio (LDR) karena semakin baik Total Aset perusahaan maka Proporsi Pendapatan Operasional Selain Bunga akan semakin meningkat dan sebaliknya jika Total Aset perusahaan menurun maka Proporsi Pendapatan Operasional Selain Bunga akan semakin menurun. Begitu pula dengan Loan to Deposit Ratio (LDR) yang mempengaruhi besar kecilnya pengaruh Total Aset terhadap Proporsi Pendapatan Operasional Selain Bunga pada Industri Perbankan di Indonesia. Selain itu pada penelitian ini menghasilkan nilai koefisien determinasi yang tidak terlalu besar, sehingga untuk peneliti selanjutnya diperlukan pengujian dengan menambahkan faktor-faktor lain yang mempengaruhi Proporsi Pendapatan Operasional Selain Bunga pada Industri Perbankan di Indonesia.

Bank (Return On Asset/ROA)(Studi Kasus pada Bank Umum pada periode 2007 - 2011). Malang : Jurnal Ilmiah Fakultas Ekonomi dan Bisnis Universitas Brawijaya.

Rastito. (2008). Analisa Pengaruh Aset, Kredit, dan Pendapatan Bunga, terhadap Laba Bank di Indonesia Tahun 2002 - 2006. Jakarta : Tesis Pasca Sarjana Universitas Terbuka.

Riduwan dan Kuncoro, Engkos Achmad. (2014). Cara Menggunakan dan Memaknai Path Analysis (Analisis Jalur) (cetakan keenam). Bandung : Alfabeta.

Sahpony, Syefrizal dan Kamaludin, Kamaludin dan Paulus, Suluk Kananlua. (2009). Pengaruh Aset Total, Dana Pihak Ketiga, Pendapatan Non Bunga dan Ekuitas terhadap Laba Bersih (Studi Kasus PT Bank Bengkulu). Bengkulu.

Stiroh, Kevin J. (2004) (forthcoming a) Diversification in Banking: Is Noninterest Income the Answer?. Journal of Money, Credit, and Banking. 
Sugiyono. (2013). Statistika Untuk Penelitian (cetakan kedua puluh tiga). Bandung: Alfabeta.

Sunyoto, Dadang. (2011). Analisis Regresi dan Uji Hipotesis. Yogyakarta : CAPS.
Taswan. (2013). Akuntansi Perbankan (Transaksi Dalam Valuta Rupiah), Edisi III (cetakan ketiga). Yogyakarta : UPP STIM YKPN.

Website Bank Indonesia : http://www.bi.go.id/id/publikasi/lapora n-keuangan. 